\title{
EFEKTIVITAS Pseudomonas fluorescens DAN Paenibacillus polymyxa TERHADAP KEPARAHAN PENYAKIT KARAT DAN HAWAR DAUN SERTA PERTUMBUHAN TANAMAN JAGUNG MANIS (Zea mays var. saccharata)
}

\author{
Galih Prasetyo, Suskandini Ratih, Ivayani \& Hasriadi Mat Akin \\ Jurusan Agroteknologi, Fakultas Pertanian Universitas Lampung \\ J1. Prof. Dr. Soemantri Brodjonegoro, No. 1 Bandar Lampung 35145 \\ E-mail: galihprazetyo3@gmail.com
}

\begin{abstract}
ABSTRAK
Penyakit penting pada tanaman jagung diantaranya adalah penyakit karat daun yang disebabkan oleh jamur Puccinia sorghi Schwein dan penyakit hawar daun yang disebabkan oleh jamur Helmithosporium turcicum Leonard et Suggs. Penelitian ini bertujuan untuk menguji keefektifan Pseudomonas fluorescens dan Paenibacillus polymyxa dalam menekan perkembangan penyakit karat dan hawar daun jagung serta memicu pertumbuhan tanaman jagung. Penelitian ini dilakukan pada bulan September sampai bulan Desember 2015 di Laboratorium Penyakit Tumbuhan Jurusan Agroteknologi dan di lahan petani di Kampung Baru Bandar Lampung. Perlakuan disusun dalam rancangan acak lengkap (RAL) terdiri atas lima perlakuan dan tiga ulangan. Perlakuan terdiri atas (1) P0 kontrol berupa tanaman jagung yang tidak diberi perlakuan fungisida, $P$. polymyxa dan P.fluorescens (2) P1 perendaman benih jagung dalam formulasi $P$. polymyxa selama 6 jam, (3) P2 perendaman benih jagung dalam formulasi P. fluorescens selama 6 jam, (4) P3 perendaman benih jagung dalam formulasi P. polymyxa dan P.fluorescens selama 6 jam, (5) P4 perendaman benih jagung dalam fungisida propineb selama 6 jam. Data yang diperoleh kemudian dianalisis dengan menggunakan sidik ragam kemudian dilanjutkan dengan uji Beda Nyata Terkecil (BNT) pada tarif nyata 5\%. Hasil penelitian menunjukkan bahwa (1) Aplikasi $P$. fluorescens dan $P$. polymyxa mampu menekan keparahan penyakit karat dan hawar daun jagung (2) Aplikasi $P$. polymyxa mampu meningkatkan tinggi tanaman dan jumlah daun jagung.
\end{abstract}

Kata kunci: Hawar daun, Helmithosporium turcicum, jagung, karat daun, Paenibacillus polymyxa, Pseudomonas fluorescens, Puccinia sorghi Schwein.

\section{PENDAHULUAN}

Di Indonesia, jagung manis mula-mula dikenal dalam kemasan kalengan impor. Menurut Jugenheimer (1958), jagung manis (Zea mays var. saccharata) biasanya dikonsumsi sebagai sayuran beku atau sayuran kaleng dan dalam keadaan segar. Jagung manis dimakan segar setelah dimasak. Jagung manis dalam jumlah besar lazim juga dikalengkan, sedangkan bijinya dibekukan setelah dipipil dari tongkolnya. Jagung yang masih bertongkol juga lazim diolah dengan dibekukan (Rubatzky \& Yamaguchi, 1998).

Kebutuhan akan tersedianya jagung manis semakin tahun semakin meningkat. Berdasarkan data dari BPS (2011), pada tahun 2008 - 2010, ekspor jagung manis mengalami penurunan sebesar $17,25 \%$ per tahun, sedangkan impor jagung manis mengalami peningkatan sebesar $6,26 \%$ per tahun. Hal ini menandakan bahwa produksi jagung manis nasional belum dapat mencukupi permintaan pasar.

Penyakit penting pada tanaman jagung diantaranya adalah penyakit karat daun yang disebabkan oleh jamur Puccinia sorghi Schwein dan penyakit hawar daun yang disebabkan oleh jamur Helmithosporium turcicum (Pass.) Leonard et Suggs (Semangun, 2004).

Penyakit karat daun disebabkan oleh jamur Puccinia sorghi. Gejala awal berupa bercak-bercak merah dan keluar serbuk seperti tepung berwarna coklat kekuningan. Akibat penyakit ini, tanaman tidak dapat melakukan fotosintesis dengan sempurna sehingga pertumbuhannya melambat, bahkan tanaman dapat mati. P. sorghi lebih banyak terdapat di pegunungan tropik dan di daerah beriklim sedang. Kerugian yang ditimbulkan oleh penyakit ini mencapai 70\%

Penyakit hawar daun termasuk penyakit penting tanaman jagung dan telah menyebar di banyak negara di Amerika, Asia, Afrika, dan Eropa. Kerugian yang diakibatkan oleh penyakit ini mencapai 50\%. Pada awal infeksi gejala berupa bercak kecil, berbentuk oval kemudian bercak semakin memanjang berbentuk ellips dan berkembang menjadi nekrotik dan disebut hawar, berwarna hijau keabu-abuan atau coklat (Wakman \& Burhanudin, 2004). Pengendalian penyakit tanaman 
jagung yang sering dilakukan petani selama ini ialah dengan menggunakan fungisida kimiawi. Pengendalian penyakit dengan cara ini mempunyai dampak negatif. Beberapa dampak negatif diantaranya adalah matinya organisme non-target yang menyebabkan berkurangnya keanekaragaman hayati dan terganggunya ekosistem. Dampak lain yang dapat terjadi adalah resistensi pada target, kontaminasi pada bahan pangan, keracunan bagi operator, dan pencemaran lingkungan (Djojosumarto, 2000).

Oleh karena itu, perlu dicarikan alternatif pengendalian lainnya yaitu dengan penggunaan agensia hayati. Penggunaan agensia hayati berpotensi tinggi menghambat serangan patogen, mampu beradaptasi dan berkolonisasi pada perakaran tanaman. Bakteri yang dapat dijadikan sebagai agensia hayati diantaranya adalah Pseudomonas fluorescens dan Paenibacillus polymyxa. Kedua bakteri ini bukan saja antagonis terhadap patogen, tetapi juga merupakan bakteri yang dapat berfungsi sebagai PGPR (plant growth promoting rhizobacteria), dan dapat menginduksi ketahanan sistemik tanaman. Penggunaan bakteri ini dilaporkan telah meningkatkan pertumbuhan dan produksi pada tanaman pertanian. Nawangsih (2006) menggunakan $P$. fluorescens dalam menghambat keparahan penyakit pada tomat yang disebabkan oleh Rhizoctonia solanacearum pada tomat. Haggag \& Mohammad (2007) juga melaporkan bahwa bakteri $P$. polymyxa dapat menginduksi ketahanan kacang tanah terhadap penyebab penyakit busuk mahkota (Apergillus niger).

Uraian diatas menunjukkan bahwa $P$. fluorescens dan $P$. polymyxa memiliki kemampuan untuk menekan pertumbuhan jamur patogen, sehingga dimungkinkan bakteri ini dapat mengurangi intensitas penyakit pada tanaman jagung. Oleh karena itu dianggap perlu untuk melakukan penelitian ini.

\section{BAHAN DAN METODE}

Penelitian ini dilaksanakan di Laboratorium Penyakit Tumbuhan Jurusan Agroteknologi dan di lahan petani di Kampung Baru Bandar Lampung dari bulan September 2015 sampai bulan Desember 2015.Alat yang digunakan dalam penelitian ini adalah cawan Petri, erlenmeyer, pembakar bunsen, kaca preparat dan penutupnya, mikroskop majemuk, jarum ose, autoklaf, plastik tahan panas, alumunium foil, cangkul, penggaris dan alat tulis. Bahan-bahan yang digunakan dalam penelitian ini adalah benih jagung manis Osse, formulasi $P$. polymyxa dan isolat $P$. fluorescens dengan masa simpan 15 bulan, fungisida berbahan aktif propineb $70 \%$ dan akuades steril.
Penelitian disusun dalam rancangan acak lengkap (RAL) terdiri atas lima perlakuan dan tiga ulangan. Perlakuan terdiri atas (1) P0 kontrol berupa tanaman jagung yang tidak diberi perlakuan fungisida, $P$. polymyxa dan $P$. fluorescens (2) P1 perendaman benih jagung dalam formulasi $P$. polymyxa selama 6 jam, (3) P2 perendaman benih jagung dalam formulasi $P$. fluorescensselama 6 jam, (4) P3 perendaman benih jagung dalam formulasi P. polymyxa dan P.fluorescens selama 6 jam, (5) P4 perendaman benih jagung dalam fungisida propineb selama 6 jam. Layout penelitian dapat dilihat pada Gambar 1.

Formulasi $P$. polymyxa dan $P$. fluorescens diperoleh dari BPTP (Balai Pengkajian Teknologi Pertanian) Lampung. Benih jagung manis Jambore direndam dalam formulasi $P$. polymyxa dan $P$. fluorescensselama 6 jam. Inokulasi hawar daun dan karat daun dilakukan saat tanaman berumur 14 hari dan 21 hari setelah tanam dengan cara menyiramkan $2 \mathrm{ml}$ suspensi inokulum penyebab hawar dan karat ke daun corong dan menyemprotkan suspensi ke daun corong. Suspensi inokulum dibuat dengan cara mencari daun tanaman yang terserang hawar dan karat daun, kemudian daun tersebut dipotong kecil-kecil dan dimasukkan kedalam $1000 \mathrm{ml}$ aquades yang sudah dilarutkan gula sebanyak 10 g.Benih jagung ditanam pada lahan yang disiapkan dengan luas lahan $3 \times 6 \mathrm{~m}$. Setiap lubang tanam diberi dua benih jagung. Jarak tanam jagung $25 \times 75 \mathrm{~cm}$. Pemupukan dilakukan dengan pupuk NPK dengan dosis $180 \mathrm{~kg} / \mathrm{ha}$.

Pengamatan dilakukan pada keparahan penyakit tanaman jagung dan masa inkubasi. Keparahan penyakit

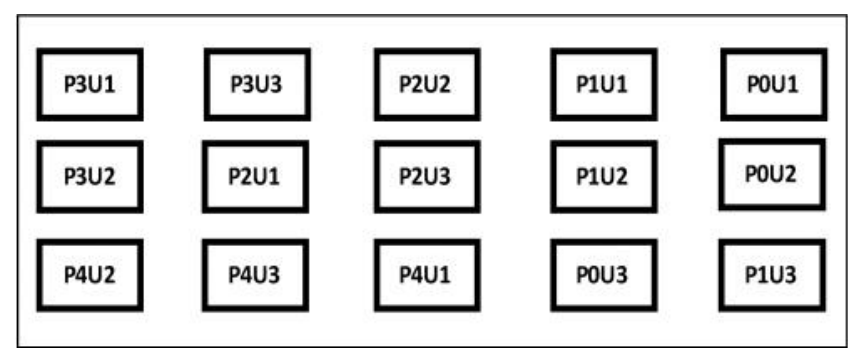

Gambar 1. Layout petak percobaan. $\mathrm{P} 0=$ kontrol, $\mathrm{P} 1=$ perendaman benih jagung dalam formulasi $P$. polymyxa selama 6 jam, $\mathrm{P} 2=$ perendaman benih jagung dalam formulasi $P$. fluorescensselama 6 jam, P3 = perendaman benih jagung dalam formulasi $P$. polymyxa dan $P$. fluorescens selama 6 jam, P4 = perendaman benih jagung dalam fungisida propineb selama 6 jam, U1 = ulangan 1, U2 $=$ ulangan 2 , dan $\mathrm{U} 3=$ ulangan 3. 
dihitung dengan rumus yang dikemukakan oleh James (1971) :

$$
\mathrm{KeP}=\frac{\sum n x v}{Z x N} \times 100 \%
$$

Keterangan :

$\mathrm{KeP}=$ keparahan penyakit

$\mathrm{n} \quad=$ jumlah jaringan terserang di tiap kategori (skor)

$\mathrm{N}=$ kategori (skor) serangan

$\mathrm{Z}=$ kategori serangan tertinggi

$\mathrm{N}$ = total dari jumlah jaringan yang diamati

Skoring keparahan penyakit sebagai berikut :

Skor $0=0 \%$ luas daun yang bergejala

Skor $1=1-20 \%$ luas daun yang bergejala

Skor $2=21-40 \%$ luas daun yang bergejala

Skor $3=41-60 \%$ luas daun yang bergejala

Skor $4=61-80 \%$ luas daun yang bergejala

Data penunjang adalah tinggi tanaman yang diukur dari permukaaan tanah sampai ujung titik daun. Pengukuran dilakukan dari tanaman jagung berumur 7 hari setelah tanam. Data dianalisis dengan sidik ragam kemudian dilanjutkan dengan uji coba Beda Nyata Terkecil (BNT) pada tarif nyata 5\%.

\section{HASIL DAN PEMBAHASAN}

\section{A. Hasil}

\section{Penyakit Karat Daun (Puccinia sorghi)}

Penyakit karat daun mempunyai gejala awal berupa bercak-bercak kecil kuning. Bercak tersebut tersebar pada permukaan daun dan mengakibatkan daun menjadi kering pada saat terjadi infeksi lanjut (Gambar 2a). Penyakit karat daun disebabkan oleh P. sorghi. Konidiajamur $P$. sorghi berwarna coklat, berdinding coklat kemerahan, berbentuk tabung atau gada, tumpul atau agak meruncing, biasanya agak mengecil pada sekat (Gambar 2b).

Perkembangan keparahan penyakit karat daun jagung manis pada masing-masing perlakuan setiap minggunya menunjukkan peningkatan. Pada minggu ke8 keparahan penyakit karat daun rata-rata pada perlakuan kontrol dan fungisida tidak berbeda nyata yaitu sebesar $42,96 \%$ dan $44,10 \%$, sedangkan persentase keparahan penyakit hawar daun pada perlakuan $P$. polymyxa, $P$. fluorescens, maupun $P$. polymyxa dan $P$. fluorescens yaitu sebesar $29,17 \%$, $39,17 \%$, dan 32,31\% (Tabel 1). Hasil penelitian menunjukkan bahwa perlakuan $P$. fluorescens dan $P$. polymyxa mampu mengurangi keparahan penyakit karat daun jagung manis dibandingkan perlakuan kontrol dan fungisida. Fungisida yang berbahan aktif propinep ini memang digunakan untuk tanaman jagung manis, namun bukan untuk perlakuan benih sehingga jelas tidak efektif untuk perlakuan benih.

\section{Penyakit Hawar Daun (Helminthosporium turcicum)}

Berdasarkan pengamatan terhadap gejala penyakit hawar daun, terlihat bahwa pada awal terinfeksi, gejala berupa bercak kecil, kemudian bercak semakin memanjang berbentuk ellips dan berkembang menjadi nekrotik yang disebut hawar, warnanya hijau keabu-abuan atau coklat (Gambar 2c). Jamur ini tidak menginfeksi tongkol atau klobot jagung manis. Bercak muncul dimulai pada daun yang terbawah kemudian berkembang menuju daun atas.

Helminthosporium turcicum mempunyai konidiofor tegak dan kuat, berwarna coklat. Konidium seperti kumparan atau seperti gada panjang, sering agak bengkok, bersekat banyak berwarna coklat dan berdinding tebal (Gambar 2d). Pengamatan pada minggu ke-4 sampai minggu ke-8 menunjukkan bahwa perlakuan $P$. fluorescens dan $P$. polymyxa mampu mengurangi keparahan penyakit hawar daun jagung manis dibandingkan perlakuan kontrol. Perkembangan keparahan penyakit hawar daun jagung manis pada masing-masing perlakuan $P$. fluorescens, $P$. polymyxa sertacampuran $P$. fluorescens dan $P$. polymyxa setiap minggunya menunjukkan peningkatan. Pada minggu ke8 keparahan penyakit hawar daun rata-rata tertinggi pada perlakuan kontrol yaitu mencapai $18,70 \%$ sedangkan persentase keparahan penyakit hawar daun

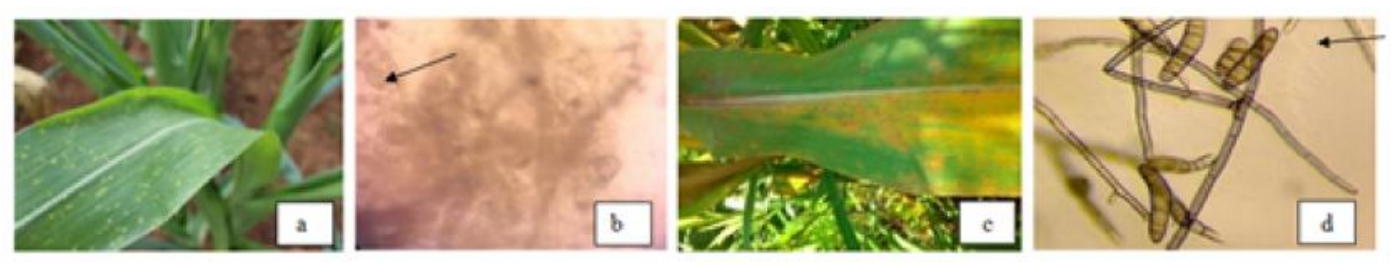

Gambar 2. (a) gejala karat daun, (b) Konidia Puccinia sorghi, (c) Gejala hawar daun, (d) Konidia Helminthosporium (Sumber: Soenartiningsih \& Fatmawati 2012). 
yang paling rendah terdapat pada perlakuan $P$. polymyxa yaitu sebesar $6,14 \%$, namun secara statistik perlakuan P. fluorescens dan P. polymyxa (P1, P2, P3, P4) ini tidak berbeda nyata (Tabel 2).

\section{Tinggi tanaman}

Hasil pengamatan menunjukkan bahwa perlakuan berpengaruh terhadap tinggi tanaman. Pengamatan pada minggu ke-1 sampai minggu ke-8 menunjukkan bahwa perlakuan P1 ( $P$. polymyxa) memiliki tinggi tanaman tertinggi, sedangkan perlakuan lainnya (P0, P2, P3, P4) tidak berbeda nyata. Pada minggu ke- 8 , tinggi tanaman jagung manis tertinggi pada perlakuan P1 (P. polymyxa) yaitu sebesar $160,13 \mathrm{~cm}$, sedangkan tinggi tanaman jagung manis perlakuan kontrol, $P$. fluorescens, $P$. polymyxa dan $P$. fluorescens dan fungisida yaitu 146,53 $\mathrm{cm}, 136,2 \mathrm{~cm}, 111,77 \mathrm{~cm}$ dan 140,57 cm (Tabel 3).

\section{$\underline{\text { Jumlah daun }}$}

Hasil pengamatan pada minggu ke-1 sampai minggu ke-7 menunjukkan bahwa perlakuan berpengaruh terhadap jumlah daun. Namun pada pengamatan minggu ke-8 menunjukkan bahwa perlakuan tidak berbeda nyata (Tabel 4).

\section{B. Pembahasan}

Hasil penelitian menunjukkan bahwa perlakuan $P$. fluorescens dan P. polymyxa mampu mengurangi

Tabel 1. Keparahan penyakit karat daun jagung manis pada berbagai perlakuan

\begin{tabular}{cccccc}
\hline & \multicolumn{4}{c}{ Keparahan penyakit (\%) pada pengamatan minggu ke- $(*)$} \\
\cline { 2 - 6 } Perlakuan & 4 & 5 & 6 & 7 & 8 \\
\hline P0 & $11,20 \mathrm{~b}$ & $21,67 \mathrm{c}$ & $29,81 \mathrm{~b}$ & $36,30 \mathrm{c}$ & $42,96 \mathrm{~b}$ \\
P1 & $4,09 \mathrm{a}$ & $6,74 \mathrm{~b}$ & $9,62 \mathrm{a}$ & $15,53 \mathrm{a}$ & $29,17 \mathrm{a}$ \\
P2 & $1,67 \mathrm{a}$ & $4,29 \mathrm{a}$ & $8,69 \mathrm{a}$ & $23,93 \mathrm{ab}$ & $39,17 \mathrm{a}$ \\
P3 & $2,41 \mathrm{a}$ & $3,24 \mathrm{a}$ & $6,48 \mathrm{a}$ & $30,65 \mathrm{bc}$ & $32,31 \mathrm{a}$ \\
P4 & $2,31 \mathrm{a}$ & $4,84 \mathrm{ab}$ & $10,73 \mathrm{a}$ & $42,83 \mathrm{~d}$ & $44,10 \mathrm{~b}$ \\
\hline
\end{tabular}

Keterangan: (*) Angka-angka yang diikuti oeh huruf yang sama menunjukkan tidak berbeda nyata berdasarkan uji BNT pada taraf 5\%. P0 = kontrol berupa tanaman jagung manis yang tidak diberi perlakuan fungisida propineb, P. polymyxa dan P.fluorescens, $\mathrm{P} 1=$ perendaman benih jagung manis dalam formulasi $P$. polymyxa selama 6 jam, $\mathrm{P} 2=$ perendaman benih jagung manis dalam formulasi $P$. fluorescens selama 6 jam, P3 = perendaman benih jagung manis dalam formulasi P. polymyxa dan P. fluorescens selama 6 jam, $\mathrm{P} 4=$ perendaman benih jagung manis dalam fungisida propineb selama 6 jam.

Tabel 2. Keparahan penyakit hawar daun jagung manis pada berbagai perlakuan

\begin{tabular}{cccccc}
\hline Perlakuan & \multicolumn{4}{c}{ Keparahan penyakit $(\%)$ pada pengamatan minggu ke- $(*)$} \\
\cline { 2 - 6 } & 4 & 5 & 6 & 7 & 8 \\
\hline P0 & $4,07 \mathrm{~b}$ & $6,48 \mathrm{~b}$ & $9,72 \mathrm{~b}$ & $12,96 \mathrm{~b}$ & $18,70 \mathrm{~b}$ \\
P1 & $0,61 \mathrm{a}$ & $2,05 \mathrm{a}$ & $3,48 \mathrm{a}$ & $4,09 \mathrm{a}$ & $6,14 \mathrm{a}$ \\
P2 & $0,95 \mathrm{a}$ & $3,57 \mathrm{a}$ & $4,40 \mathrm{a}$ & $5,24 \mathrm{a}$ & $7,02 \mathrm{a}$ \\
P3 & $0,83 \mathrm{a}$ & $3,24 \mathrm{a}$ & $3,98 \mathrm{a}$ & $4,72 \mathrm{a}$ & $7,13 \mathrm{a}$ \\
P4 & $1,57 \mathrm{a}$ & $4,10 \mathrm{a}$ & $5,05 \mathrm{a}$ & $7,58 \mathrm{a}$ & $7,58 \mathrm{a}$ \\
\hline
\end{tabular}

Keterangan : (*) Angka-angka yang diikuti oeh huruf yang sama menunjukkan tidak berbeda nyata berdasarkan uji BNT pada taraf 5\%. P0 = kontrol berupa tanaman jagung manis yang tidak diberi perlakuan fungisida propineb, P. polymyxa dan P.fluorescens, $\mathrm{P} 1=$ perendaman benih jagung manis dalam formulasi $P$. polymyxa selama 6 jam, $\mathrm{P} 2=$ perendaman benih jagung manis dalam formulasi $P$. fluorescens selama 6 jam, P3 = perendaman benih jagung manis dalam formulasi $P$. polymyxa dan $P$. fluorescens selama 6 jam, $\mathrm{P} 4=$ perendaman benih jagung manis dalam fungisida propineb selama 6 jam. 
Tabel 3. Pengaruh perlakuan terhadap tinggi tanaman jagung manis

\begin{tabular}{|c|c|c|c|c|c|c|c|c|}
\hline \multirow[t]{2}{*}{ Perlakuan } & \multicolumn{8}{|c|}{ Tinggi tanaman $(\mathrm{cm})$ pada pengamatan minggu ke- $(*)$} \\
\hline & 1 & 2 & 3 & 4 & 5 & 6 & 7 & 8 \\
\hline$\overline{\mathrm{P} 0}$ & $20,87 \mathrm{a}$ & $50,83 \mathrm{a}$ & $81 \mathrm{a}$ & $97,07 \mathrm{a}$ & $103,13 \mathrm{a}$ & $129,5 \mathrm{bc}$ & $144,1 \mathrm{~b}$ & $146,53 \mathrm{a}$ \\
\hline $\mathrm{P} 1$ & $31,5 \mathrm{~b}$ & $79,83 \mathrm{~b}$ & $108,17 \mathrm{~b}$ & $132,47 \mathrm{~b}$ & $143,20 \mathrm{~b}$ & $154,1 \mathrm{c}$ & $160,4 \mathrm{~b}$ & $160,13 \mathrm{~b}$ \\
\hline P2 & $20,93 \mathrm{a}$ & $58,07 \mathrm{a}$ & $80,5 \mathrm{a}$ & $90,17 \mathrm{a}$ & $101,60 \mathrm{a}$ & $107,1 \mathrm{ab}$ & $134,3 \mathrm{ab}$ & $136,2 \mathrm{a}$ \\
\hline P3 & $24,1 \mathrm{a}$ & $56,4 \mathrm{a}$ & $76,6 \mathrm{a}$ & $85,63 \mathrm{a}$ & $90,07 \mathrm{a}$ & $95,57 \mathrm{a}$ & $105,57 \mathrm{a}$ & $111,77 \mathrm{a}$ \\
\hline P4 & $23,27 \mathrm{a}$ & $53,2 \mathrm{a}$ & $76,5 \mathrm{a}$ & $86,23 \mathrm{a}$ & $93,1 \mathrm{a}$ & $100,5 \mathrm{a}$ & $131,83 \mathrm{a}$ & $140,57 \mathrm{a}$ \\
\hline
\end{tabular}

Keterangan: (*) Angka-angka yang diikuti oeh huruf yang sama menunjukkan tidak berbeda nyata berdasarkan uji BNT pada taraf 5\%. P0 = kontrol berupa tanaman jagung manis yang tidak diberi perlakuan fungisida propineb, P. polymyxa dan P.fluorescens, $\mathrm{P} 1=$ perendaman benih jagung manis dalam formulasi $P$. polymyxa selama 6 jam, P2 = perendaman benih jagung manis dalam formulasi $P$. fluorescens selama 6 jam, P3 = perendaman benih jagung manis dalam formulasi P. polymyxa dan P. fluorescens selama 6 jam, $\mathrm{P} 4=$ perendaman benih jagung manis dalam fungisida propineb selama 6 jam.

Tabel 4. Pengaruh perlakuan terhadap jumlah daun jagung manis

\begin{tabular}{clllllllll}
\hline Perlakuan & \multicolumn{7}{c}{ Jumlah daun (helai) pada pengamatan } & minggu ke- $(*)$ & \\
\cline { 2 - 8 } & & & 2 & 3 & 4 & 5 & 6 & 7 & 8 \\
\hline P0 & $3 \mathrm{a}$ & $6,33 \mathrm{a}$ & $7,67 \mathrm{ab}$ & $8,33 \mathrm{a}$ & $9 \mathrm{a}$ & $11 \mathrm{ab}$ & $11 \mathrm{a}$ & $10,67 \mathrm{a}$ \\
P1 & $3,67 \mathrm{~b}$ & $8,33 \mathrm{~b}$ & $10,00 \mathrm{c}$ & $10,00 \mathrm{~b}$ & $11,67 \mathrm{~b}$ & $12 \mathrm{~b}$ & $11,67 \mathrm{ab}$ & $11 \mathrm{a}$ \\
P2 & $3 \mathrm{a}$ & $6,33 \mathrm{a}$ & $6,67 \mathrm{a}$ & $7,67 \mathrm{a}$ & $8,33 \mathrm{a}$ & $10,33 \mathrm{a}$ & $11,33 \mathrm{a}$ & $11 \mathrm{a}$ \\
P3 & $3,33 \mathrm{a}$ & $7,67 \mathrm{ab}$ & $8,00 \mathrm{~b}$ & $8,33 \mathrm{ab}$ & $8,33 \mathrm{a}$ & $10 \mathrm{a}$ & $10 \mathrm{a}$ & $10 \mathrm{a}$ \\
P4 & $3 \mathrm{a}$ & $7 \mathrm{a}$ & $7,33 \mathrm{a}$ & $8,00 \mathrm{a}$ & $8,67 \mathrm{a}$ & $12 \mathrm{~b}$ & $12,67 \mathrm{~b}$ & $12,33 \mathrm{a}$ \\
\hline
\end{tabular}

Keterangan: (*) Angka-angka yang diikuti oeh huruf yang sama menunjukkan tidak berbeda nyata berdasarkan uji BNT pada taraf 5\%. P0 = kontrol berupa tanaman jagung manis yang tidak diberi perlakuan fungisida propineb, $P$. polymyxa dan P.fluorescens, $\mathrm{P} 1=$ perendaman benih jagung manis dalam formulasi $P$. polymyxa selama 6 jam, P2 = perendaman benih jagung manis dalam formulasi $P$. fluorescens selama 6 jam, P3 = perendaman benih jagung manis dalam formulasi P. polymyxa dan P. fluorescens selama 6 jam, P4 = perendaman benih jagung manis dalam fungisida propineb selama 6 jam.

keparahan penyakit karat dan hawar pada tanaman jagung manis. Hasil ini mengindikasikan bahwa $P$. fluorescens dan $P$. polymyxa yang diberikan sebagai perlakuan benih mampu menginduksi ketahanan tanaman jagung manis. Hal tersebut dapat diduga keberadaan kedua bakteri yang digunakan saat perendaman benih jagung manis akan memberikan ketahanan kepada tanaman jagung manis sehingga patogen terhambat untuk menginfeksi daun jagung manis. Abadi (2003) dalam Sudantha (2010) melaporkan bahwa ketahanan terinduksi terjadi karena bagian tanaman telah diinokulasi sebelumnya oleh mikroorganisme penginduksi ketahanan tanaman seperti $P$. fluorescens dan $P$. polymyxa. $P$. fluorescens dan $P$. polymyxa mampu beradaptasi dengan baik pada akar tanaman yang mampu menghambat pertumbuhan dan aktivitas patogen atau memicu ketahanan sistemik dari tanaman terhadap patogen.

Tanaman yang diimunisasi diduga bereaksi dengan adanya agen penginduksi ketahanan. Agen penginduksi mengaktifkan pertahanan terhadap patogen pada tanaman rentan yang bersifat laten atau munculnya terlambat. Mekanisme ini meliputi akumulasi senyawa antimikrobia (fitoaleksin) tanaman dan pelindung biopolimer (lignin, kalus dan hydroxyproline yang kaya dengan glycoprotein) (Kuc, 1983).

P. fluorescens dapat membentuk siderofor, asam salisilat, pioverdin atau piokelin, yang berperan sebagai sinyal transduksi induced systemicresistance [ISR] (De Meyer \& Hofte 1997; Press et al. 2001). Senyawa ini diduga meningkatkan aktivitas gen-gen pathogenesisrelated (PR)-protein penghasil enzim 
peroksidase, $\alpha$-1,3-glukanase, atau $\alpha$-D-glukuronidase dalam tumbuhan (Leeman et al. 1996; Park \& Kloepper 2002). Ketika tumbuhan berinteraksi dengan patogen, aktivitas enzim tersebut meningkat. Zhang et al. (1998) telah membuktikan aktivitas enzim $\alpha$-1,3-glukanase meningkat dari 1,95 menjadi $3,70 \%$, dan $\alpha$ Dglukorodinase dari 32,5 menjadi 53,1\%. Maurhofer et al. (1998) mengemukakan bahwa siderofor dari $P$. fluorescens galur $\mathrm{P} 3$ mengekspresikan gen pengendali biosintesis asam salisilat. Siderofor ini dapat memperbaiki mekanisme induksi ketahanan sistemik tembakau dan tomat terhadap Tobacco necrosis virus (TNV).

Diterangkan bahwa ketahanan terimbas sebagai hasil induksi ketahanan dicirikan oleh akumulasi asam salisilat dan pathogenesis related-protein (PR-protein). Zhu et al. (2006) melaporkan bahwa tanaman pepaya yang diinduksi oleh BTH mengalami peningkatan ketahanan terhadap jamur Phytophthorapalmivora dengan cara meningkatkan aktivitas $\beta-1,3$ glukanase dan kitinase dengan memicu transkripsi gen SAR PR-1.

Mulya et al. (1996) melaporkan bahwa $P$ fluorescens strain G32r dapat menginduksi aktivitas enzim fenil alanine amoliase, enzim yang terlibat dalam ekspresi ketahanan tanaman. Bakteri ini juga menghasilkan enzim fosfatase dan asam - asam organik (Ilmer \& Schinner, 1992).

Enzim fosfatase berperan penting dalam melepaskan fosfat dari ikatan organik dalam tanah. $P$. fluorescens didugamampu mengklon dan beradaptasi dengan baik pada akar tanaman serta menggunakan eksudat akar untuk mensintesis metabolit yang mampu menghambat pertumbuhan dan aktifitas patogen atau memicu ketahanan sistemik dari tanaman terhadap patogen

Hasil penelitian menunjukkan bahwa pada berbagai pengamatan perlakuan $P$. polymyxa mampu meningkatkan tinggi tanaman jagung manis dibandingkan dengan perlakuan kontrol. Hal ini diduga karena $P$. polymyxa mampu menghasilkan auksin dan sitokinin, serta memfiksasi nitrogen seperti diungkapkan oleh Timmusk (2003). Bakteri ini diduga menghasilkan fitohormon khususnya IAA untuk pertumbuhan tanaman (Rao \& Subba, 1994).

\section{KESIMPULAN}

Berdasarkan hasil penelitian yang telah dilakukan, maka disimpulkan bahwa aplikasi $P$. fluorescens dan $P$. polymyxa mampu menekan keparahan penyakit karat dan hawar daun jagung. Aplikasi P. polymyxa mampu meningkatkan tinggi tanaman dan jumlah daun jagung.

\section{DAFTAR PUSTAKA}

Badan Pusat Statistik (BPS). 2011. Kota Bandar Lampung dalam Angka Tahun. (berbagai tahun penerbitan). BPS Kota Bandar Lampung.

De Meyer \& Hofte. 1997. Salicylic acid produced by the rhizobacterium Pseudomonas aeruginosa $7 \mathrm{NSK} 2$ induces resistance to leaf infection by Bortrytis cinerea on bean. Phytopathology. 87: 588-593.

Djojosumarto, P.A. 2000. Tehnik Aplikasi Fungisida Pertanian. Kanisius. Yogyakarta. Hlm 46.

Haggag W.M dan Mohamed H.A.L.A. 2007. Biotechnological aspects of microorganisms used in plant biological control. Word. J. Agric. Sci. 3(6): 771-776.

Ilmer, P., \& Schinner. F. 1992. Solubilization of inorganic phosphates by microorganisme isolated from forest soils. Soil Biol. Biochem. 24 (3): 389-395.

Jugenheimer, R.W. 1958. Hybrid Maize Breeding and Seed Production. FAO Agricultural Development Paper. Rome

Kuc, J. 1983. Induced systemic resistance in plant caused by fungi and bacteria, pp: 192221 dalam B.J. Deveral (Eds.), The Dynamics Host Devence Acad. Press, Sydney, New York, London.

Leeman. 1996. Iron avaibility affects ilnduction of systemic resistance to Fusarium wilt of radish by Pseudomonas fluorescens. Phytopathologi. 86:149-155.

Maurhofer, M., Hase C., Meuwly P., Metraux J.P., \& Defago G. 1994. Induction if systemic resistance of tobacco to tobacco necrosis virus by the root colonizing Pseudomonas fluorescens strain CHA0: Influence of the gac A gene and of pyoverdine production. Phytopathology 84:139- 146.

Mulya, K, M. Wanatabe, Goto M., Takikawa Y., \& Tsuyumu S. 1996. Supression of bacterial wilt diseases of tomato by root dipping with Pseudomonas flourescens PfG32: The role of antibiotic and siderophore production. Ann. Phytopath. Soc. Japan 62(2): 134-140.

Nawangsih, A.A. 2006. Seleksi dan Karakterisasi Bakteri biokontrol untuk Mengendalikan Penyakit Layu Bakteri (Ralstonia 
solanacearum) pada Tomat. [Disertasi]. Sekolah Pascasarjana, Institut Pertanian Bogor, Bogor.

Park K.S. \& Kloepper J.W. 2002. Activation of PR-la promoter by rhizobacteria that induce systemic resistance in tobacco against Pseudomonas syringae pv. tabaci. Biol Control. 18: 2-9.

Press C.M. Loper J.E. \& Kloepper J.W. 2001. Role of iron In rhizobacteria mediated induced systemic resistance of cucumber. Phytopathology 91: 593598.

Rao, N.S \& Subba.1994. Soil Microorganisms and Plant Growth. Oxford and IBM Publishing Co. London.

Rubatzky, V. E. dan Yamaguchi, 1998. World Vegetables. Van Nostrand Reinhold A division of International Thompson Publishing.

Semangun, H. 2004. Penyakit-Penyakit Tanaman Pangan di Indonesia. Gajah Mada University Press. $449 \mathrm{hlm}$.

Soenartiningsih dan Fatmawati. 2012. Evaluasi ketahanan beberapa varietas sorgum terhadap penyakit antraknose. Prosiding Seminar Nasional
Serealia Maros 3-4 Oktober 2011. Badan Penelitian Dan Pengembangan Pertanian. Pusat Penelitian dan Pengembangan Tanaman Pangan Balai Penelitian Tanaman Serealia.

Sudantha M. 2010. Pengaruh aplikasi jamur Trichoderma spp. dan serasah dalam meningkatkan ketahanan terinduksi tanaman vanili terhadap penyakit busuk batang Fusarium. Jurnal Agroteksos. 20 (1): 10-11.

Timmusk, S. 2003. Mechanism of action of the plant growth promoting rhizobacterium Paenibacillus polymyxa [Dissertation]. Uppsala, Sweden: Departemen of Cell and Molecular Biology, Uppsala University.

Wakman, W. dan Burhanudin. 2004. Pengelolaan Penyakit Prapanen Jagung. Balai Penelitian Tanaman Serealia Lain. Maros.

Zhang. 1998. Compost and compost water extract induced systemic acquired resistance in cucumber and Arabidopsis. Phytopathology. 88: 450-455.

Zhu, T., Chang S.H. dan Gil P. 2006. Target preparation for DNA microarray hybridization. Methods in Molecular Biology. 323: 349-357. 